\title{
SOCIAL MEDIA AND PRODUCTIVITY IN A RURAL AREA
}

\author{
C. Christopher Lee, Central Connecticut StateUniversity, christopher.lee@ccsu.edu \\ Jillian Warner, Chippewa County Health Department, jwarner2@lssu.edu \\ MaryMcCarthy, Central Connecticut State University, mary.mccarthy@ccsu.edu
}

\begin{abstract}
We explored the impacts of social media on the employee productivity in a rural area organization. We included the four management variables in this study. The survey data was collected. We developed four multiple regression models. Evidence shows that motivation, and job satisfaction affects productivity. Data shows flextime and social media have no significant impacts on productivity while work-life balance is inconclusive.
\end{abstract}

Keywords: Flextime, Work-life balance, Motivation, Job satisfaction, Information Systems

\section{INTRODUCTION}

In the workplace, managers constantly have to try to keep employees satisfied and engaged in their tasks. Levels of employee motivation and satisfaction regularly shift, so managers have to adapt to keep production moving at an acceptable pace. For this purpose, they may use a range of tactics including those that have been proven to work over many decades as well as unique and innovative modern ideas. Factors such as flextime and the compressed workweek can influence productivity rates. Employees who have the option of flextime generally experience more satisfaction with their jobs than those who do not participate. Employee satisfaction increases employee motivation, engagement, and productivity. Research has shown that flextime employees remain as loyal and produce the same quality of work as non-participants (Boston College Center for Work \& Family, 2000). Companies can often improve their operations by giving employees this benefit.

Regus (2011) supports this report's analysis through a study on the link between flextime and increased productivity/revenues. The study shows flextime options increasing and becoming a norm in working organizations. It also shows that flextime gives workers autonomy. Increased autonomy ultimately leads to more energized employees who use that energy to increase productivity and revenues overall. As this study used a global sample, geographic diversity serves as evidence to authenticate the validity of the flextime/productivity relationship on a large scale.

The factor of employee motivation also has an acute impact on productivity levels. A study from the Canadian Center of Science and Education (2013) supported offering the option of flextime as a sound employment practice largely because of motivation levels. The study found that flextime employees enjoy a comfortably paced work environment that creates an improved work/life balance with a lower rate of stress. This leads to higher staff motivation levels and from that higher production. While this study supplies crucial supporting evidence of the value of flextime to an employer, a literature survey finds that no prior study has tested statistical significances of a group of factors such as motivation, job satisfaction, work-life balance, social media as well as flextime and the effects they have on productivity. The business community would benefit from precise information about how these factors work together and how employment practices can impact groups differently.

Motivated by the lack of past studies, this research attempts to discover the effects of flextime, motivation, job satisfaction, work-life balance, and social networking on employee productivity through the use of an empirical study. Using data collected from a survey questionnaire of employees at a mid-sized organization in the Midwest rural area, this study will conduct a hypothesis testing through multivariate statistical analysis.

This paper proceeds with Section Two containing a literature review of past studies, Section Three the methodology, Section Four the statistical results, and Section Five the managerial implications. Lastly, Section Six concludes the study. 


\section{LITERATURE REVIEW}

The topic of identifying the impact of flexible work schedules has been concerning managers and organizations for the past four decades. A study directed by The Boston College Center for Work \& Family (2000) sought to discover the effects of flextime on productivity and work-life balance. The study sampled 1,353 employees and 151 managers using survey questions that considered retention, quality of work, impact on managers, employees and productivity. The survey originated from collaborations between six companies: Amway Corporation, Bristol-Myers Squibb Company, Honeywell, Kraft Foods, Lucent Technologies, and Motorola Incorporated. The results made a strong case for flextime at work. A majority of managers and employees (70 percent) reported positive productivity impacts. Nearly 90 percent of employees reported a positive impact on quality of work, and almost 40 percent of employees reported that flextime helped them to create a good work-life balance. Only 25 percent of non-flextime employees felt that they had a good work-life balance, however.

Rocereto, Gupta, \& Mosca (2011) researched employee attitudes on flextime and then compared the work-life balance and job satisfaction of those employees with flextime to those without. This study used questionnaires to sample 135 employees from an assorted array of industries. Using a one-way ANOVA, the study showed that the appeal of flextime for users and non-users was higher than the scale neutral point. This supported the research hypothesis that flextime would appeal strongly to both groups. A correlation analysis showed a positive relationship between work-family balance and job satisfaction for both groups. From the findings, one can surmise that most employees desire to have a flexible work schedule. Those who have one already enjoy positive work-family balances and high job satisfaction. They found factors producing satisfaction and work-life balance also produce motivation. Organizations and managers try to motivate employees to perform to their highest capabilities. A balanced mix of intrinsic and extrinsic motivators should be present in the workplace and managers need to adapt to employee needs in order to achieve motivation. For employers to capitalize on productivity gains through a good work-life balance they need to provide employees with different options and benefits that allow work to stay at work and not take over their lives.

The large amount of research on how flextime affects employees motivated Baltes, Briggs, Huff, Wright, \& Nueman (1999) to expand on those findings regarding flextime. In 95 percent significance tests, flexible workweeks had positive influences on productivity, job satisfaction, and work-schedule satisfaction. The flextime-specific regression analysis upheld predictions that flextime has positive effects on productivity. It is important to note the size of the effects differed. For example the effects of absenteeism compared to productivity substantially differed. When employees rated their own performances, they tended to report the same effectiveness for themselves even though productivity increased. They argued that job satisfaction related to productivity. Job satisfaction keeps employees engaged and in tune with organizational goals and objectives. Dissatisfaction produces a high turnover rate and ultimately costs organizations time and money. Disgruntled workers also create a toxic internal environment that affects productivity. The authors used meta-analytic techniques to estimate the effects of flexible and compressed workweek schedules on several work-related criteria (productivity/performance, job satisfaction, absenteeism, and satisfaction with work schedule). In general, the effects of both schedules were positive. However, the effects of both flextime and compressed workweek schedules differed across the outcome criteria (e.g., compressed workweek schedules did not significantly affect absenteeism). Thus, the level of positive impact associated with either schedule depended on the outcome criterion under consideration. Further, the researchers found several variables to be moderators of flexible work schedules. For example, the researchers found highly flexible flextime programs to be less effective in comparison to less flexible programs. They also found that the positive benefits of flextime schedules diminished over time.

Magnier-Wantanabe, Wantanabe, and Yoshida (2010) conducted a study aimed at finding the effect of intranetbased social networking services on business connections and time/cost-savings. The Economic Research Center of the Fujitsu Research Institute in Tokyo collected data from 1,362 surveys. Through conducting a stepwise regression analysis, the researchers found that social networking services improve an employee's number of business connections and encourage innovation in the workplace.

Many studies analyze the impacts flextime has on productivity. Others examine its relation to job satisfaction, motivation, work-life balance, or social networking applications individually. No study, however, was found that included all the variables of productivity; thus, this study attempts to fill this gap in literature. The study proposes a 
framework of productivity factors that organizations will benefit from increasing/implementing. This study also hypothesizes that as each variable increases, organizational productivity will follow suit.

Flextime has been an important factor in driving productivity for the last 30 years. Flextime increases productivity through a direct relationship with motivation, satisfaction, and work-life balance as well. Flextime can be defined as a flexible work schedule where an employee has autonomy in selecting work hours while still getting in the hours demanded by their job. Generally, flextime scheduling provides employees with more control and convenience which aid in producing positive work outcomes such as quality of work (Boston College Center for Work and Family, 2000)

$\mathrm{H}_{1}$ : Flextime has a positive relationship with productivity.

Another factor of productivity is employee motivation. Organizations and managers try to motivate employees to perform to their highest capabilities. A balanced mix of intrinsic and extrinsic motivators should be present in the workplace and managers need to adapt to employee needs in order to achieve motivation. One way to motivate employees was to provide the opportunity for flextime in the workplace. Gupta, Mosca, \& Rocereto (2011) found factors producing satisfaction and work-life balance will produce motivation

$\mathrm{H}_{2}$ : Motivation makes positive impacts on productivity.

Job satisfaction is a must for employees to stay engaged and in tune with organizational goals and objectives. If workers are not satisfied there will be a high turnover rate and will ultimately cost the organization time and money. Disgruntled workers also create a toxic internal environment that does not strive for synergy and goal-completion; this affects productivity because unsatisfied workers tend to put less effort into the job. Baltes, Briggs, Huff, Wright \& Nueman (1999) found job satisfaction to be linked to productivity.

$\mathrm{H}_{3}$ : Job satisfaction affects productivity positively.

A good balance between work and personal life is an important part of keeping employees happy about their job. This is found to be especially important for women with children; family is the most important thing to many people. For employers to capitalize on productivity gains through a good work-life balance they will recognize the need and provide employees with different options and benefits that allow work to stay at work and not take over their lives. Rocereto et al. (2011) conducted a study which showed that employees whom participated in flextime programs experienced a much higher work-life balance.

$\mathrm{H}_{4}$ : Work-life balance is positively related to productivity.

Communicating with your employees and peers outside of work is an important part in maintaining employee internal relationships. This keeps conflict between employees down and increases positive responses between workers and managers. Social networking can help employees feel a need of belongingness. A study by MagnierWantanabe, Wantanabe, \& Yoshida (2010) showed that social networking services were found to encourage innovation in the workplace. Meister (2013) also argued that social media could lead to higher employee productivity.

\section{$\mathrm{H}_{5}$ : Social media has a positive impact on productivity}

In summary, a main hypothesis for this research states that productivity in the organizational setting can be improved by implementing flextime, increasing motivation, enhancing job satisfaction, increasing work-life balance, taking advantage of technology, and encouraging social media use. 


\section{RESEARCH METHODOLOGY}

The framework for this research is presented in Figure 1 below.

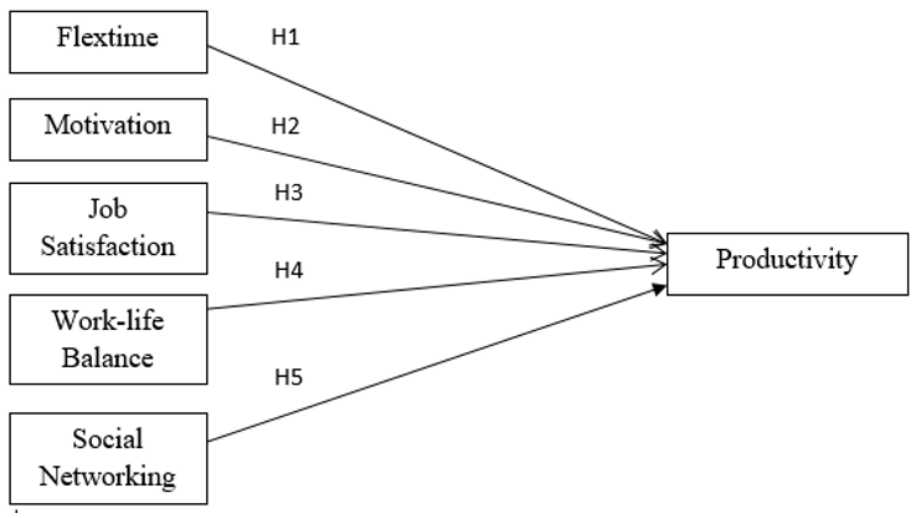

Figure 1. Research Framework

A main hypothesis for this research posits that productivity in an organizational setting can be improved by implementing flextime, increasing motivation, enhancing job satisfaction, increasing work-life balance, taking advantage of technology, and encouraging social media use. The figure below presents the framework for this research.

This study uses a multiple regression model to conduct hypothesis testing. The multivariate statistical model uses employee productivity as a proxy for the dependent variable (Y). Using five factors describing employee benefits to serve as independent variables: flextime $\left(\mathrm{X}_{1}\right)$, motivation $\left(\mathrm{X}_{2}\right)$, job satisfaction $\left(\mathrm{X}_{3}\right)$, work-life balance $\left(\mathrm{X}_{4}\right)$, and social network $\left(\mathrm{X}_{5}\right)$.

$$
Y=\beta_{0}+\beta_{1} * X_{1}+\beta_{2} * X_{2}+\beta_{3} * X_{3}+\beta_{4} * X_{4}+\beta_{5} * X_{5}
$$

\section{RESULTS}

Out of 800+ employees, 53 randomly participated in the survey. Descriptive statistics show that out of 53 responses, 36 are females (65.4\%), 16 are males (30.8\%), and one participant $(3.8 \%)$ preferred not to disclose his or her gender. Twenty-nine people (55.8\%) were in the age category of 18 to 24 . Only 5.8 percent were between the ages of 32-38. Considering educational background, 24 participants (46\%) had some college credit but no degree, and 12 people (23 percent) had a bachelor's degree or higher. Ten employees (19.2\%) work in the educational service industry, eight (15.4\%) work in accommodations and food service industry, 21 (40.4\%) in clerical positions, and $15(28.8 \%)$ as technical workers. No participants described their job position as executive or owner/president. Eighty-seven scenarios were administered and the demographics of the sample population are shown in Table 1 . The sample population had more males $(70.1 \%)$ than females $(29.9 \%)$.

Table 1. Pearson Correlations

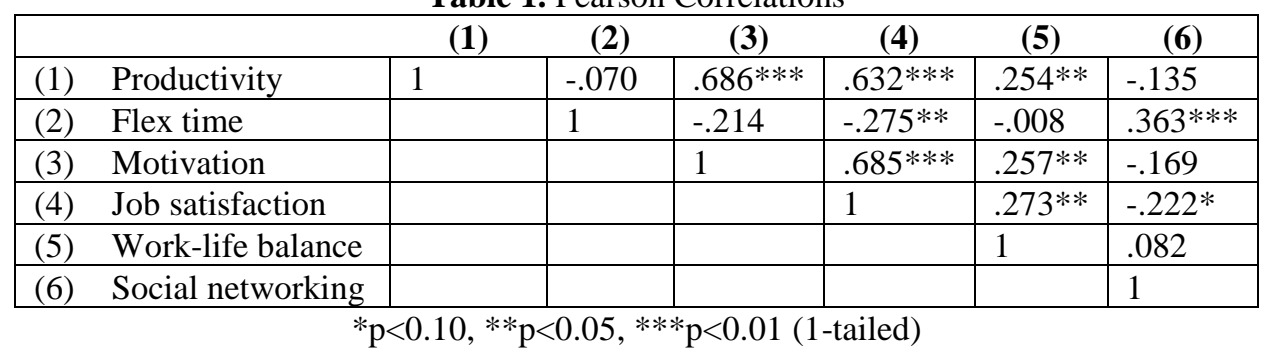




\section{Issues in Information Systems}

Volume 19, Issue 4, pp. 35-43, 2018

Results show the statistical significance in the multiple regression model on employee productivity as described in the methodology section $\left[\mathrm{R}^{2}=.549, \mathrm{~F}(5,44)=10.697, \mathrm{p}<0.05\right]$. Refer to Table 2 below. Results of the correlation matrix above show significant correlation between variables at $\mathrm{p}<0.01$ of productivity and motivation as well as job satisfaction, motivation and job satisfaction. Results of the correlation matrix above show significant correlation between variables at $\mathrm{p}<0.05$. The variables of productivity and work life balance, flextime and job satisfaction, motivation and work life balance, job satisfaction and work life balance all show strong correlation. The other factors show no statistical significance. Interestingly, this study found that flextime $(p<0.05)$ and job satisfaction $(\mathrm{p}<0.05)$ significantly affect productivity. The other productivity factors show no statistical significance. A deeper comparison of variables shows that motivation has a significant impact on the productivity of female employees. Job satisfaction, however, drives male productivity more often.

Table 2. Full Regression Model Results

\begin{tabular}{|c|c|c|c|c|c|c|}
\hline \multicolumn{7}{|c|}{ Dependent Variable $=$ Productivity; $\mathrm{R}^{2}=.549, \mathrm{~F}(5,44)=10.697 * *$} \\
\hline $\mathbf{X}_{\mathbf{j}}$ & Acronym & Source & $\mathbf{b}_{\mathbf{j}}$ & SE & SB & $\mathbf{t}$ \\
\hline (Constant) & & & .483 & 1.055 & & .458 \\
\hline $\mathrm{X}_{1}$ & Flex time & $\mathrm{Q} 8,11,13$ & .133 & .102 & .142 & $1.297 *$ \\
\hline $\mathrm{X}_{2}$ & Motivation & Q10,12,15 & .401 & .113 & .490 & $3.537 * * *$ \\
\hline $\mathrm{X}_{3}$ & Job satisfaction & $\mathrm{Q} 2,5,6$ & .231 & .113 & .291 & $2.048 * *$ \\
\hline $\mathrm{X}_{4}$ & Work-life balance & Q3,4,7,19 & .137 & .147 & .100 & .934 \\
\hline $\mathrm{X}_{5}$ & Social networking & Q9,14,16,17,20,22 & -.031 & .108 & -.031 & -.285 \\
\hline $\begin{array}{l}\text { Source } \\
b_{j} \\
\text { SE } \\
\text { SB }\end{array}$ & \multicolumn{6}{|c|}{$\begin{array}{l}\text { Item number of the survey questionnaire } \\
\text { Unstandardized regression coefficient for } \mathrm{X}_{\mathrm{j}} \\
\text { Standard error of unstandardized bj } \\
\text { Standardized coefficients for } \mathrm{X}_{\mathrm{j}}\end{array}$} \\
\hline
\end{tabular}

Because the social networking factor does not show any statistical significance in the full model, we developed a reduced model with only three predictors: motivation, job satisfaction, and work life balance. Refer to Table 3 below. Among the three independent variables, motivation variable shows the highest significance $(\mathrm{p}<.001)$. This model shows a marginal impact from job satisfaction on the productivity $(\mathrm{p}=0.063)$.

Table 3. Reduced Model 1 with 3 Predictors Only

\begin{tabular}{|l|l|l|l|l|}
\hline \multicolumn{5}{|c|}{ Dependent Variable=Productivity; $\mathrm{R}^{2}=.531, \mathrm{~F}(3,46)=17.380 * * *$} \\
\hline \multicolumn{1}{|c|}{$\mathbf{X}_{\mathbf{j}}$} & \multicolumn{1}{|c|}{$\mathbf{b}_{\mathbf{j}}$} & \multicolumn{1}{c|}{$\mathbf{S E}$} & \multicolumn{1}{c|}{$\mathbf{S B}$} & \multicolumn{1}{c|}{$\mathbf{t}$} \\
\hline Constant) & 1.117 & .855 & & 1.307 \\
\hline Motivation & .397 & .113 & .485 & $3.513^{* * *}$ \\
\hline Job satisfaction & .210 & .110 & .264 & $1.908^{*}$ \\
\hline Work-life balance & .144 & .145 & .105 & .995 \\
\hline \multicolumn{5}{|c}{$* \mathrm{p}<0.10, * * \mathrm{p}<0.05, * * * \mathrm{p}<0.001$}
\end{tabular}

We also explored gender impacts on the productivity. Table 4 reports the female model $\left[R^{2}=.482, F(4,28)=6.523\right.$, $\mathrm{p}<.05]$. Among three independent variables - motivation, work-life balance, flex time, the female model shows a high significance with the motivation variable $(\mathrm{p}=.002)$. We dropped the job satisfaction variable because it caused multicollinearity. 
Table 4. Reduced Model 2 - Female Employees Only

\begin{tabular}{|l|l|l|l|l|}
\hline \multicolumn{5}{|c|}{ Dependent Variable=Productivity; $\mathrm{R}^{2}=.482, \mathrm{~F}(4,28)=6.523 * *$} \\
\hline \multicolumn{1}{|c|}{$\mathbf{X}_{\mathbf{j}}$} & \multicolumn{1}{|c|}{$\mathbf{b}_{\mathbf{j}}$} & \multicolumn{1}{c|}{ S.E. } & \multicolumn{1}{c|}{ S.B. } & \multicolumn{1}{c|}{$\mathbf{t}$} \\
\hline (Constant) & 1.545 & 1.274 & & 1.213 \\
\hline Motivation & .564 & .163 & .701 & $3.457 * * *$ \\
\hline Work-life balance & .123 & .180 & .099 & .682 \\
\hline Flex time & .042 & .122 & .050 & .341 \\
\hline \multicolumn{5}{|c}{$\mathrm{p}<0.10, * * \mathrm{p}<0.05, * * * \mathrm{p}<0.01$}
\end{tabular}

We developed a reduced model with male employees only. Table 5 reports the male model results $\left[R^{2}=.695, F(4\right.$, $10)=5.701, \mathrm{p}<.05]$. When the male gender was tested against all the variables, job satisfaction showed to be of the highest significance and affected productivity $(\mathrm{p}=0.023)$.

Table 5. Reduced Model 3 - Male Employees Only

\begin{tabular}{|l|l|l|l|l|}
\hline \multicolumn{5}{|c|}{ Dependent Variable=Productivity; $\mathrm{R}^{2}=.695, \mathrm{~F}(4,10)=5.701 * *$} \\
\hline \multicolumn{1}{|c|}{$\mathbf{X}_{\mathbf{j}}$} & \multicolumn{1}{|c|}{$\mathbf{b}_{\mathbf{j}}$} & \multicolumn{1}{c|}{ S.E. } & \multicolumn{1}{c|}{ S.B. } & \multicolumn{1}{c|}{$\mathbf{t}$} \\
\hline (Constant) & -.483 & 2.759 & & -.175 \\
\hline Motivation & .251 & .212 & .262 & 1.183 \\
\hline Job satisfaction & .451 & .169 & .609 & $2.673 * *$ \\
\hline Work-life balance & .127 & .447 & $.053 *$ & .284 \\
\hline Flex time & .214 & .194 & .198 & 1.106 \\
\hline \multicolumn{5}{|c}{$* 0.01, * * \mathrm{p}<0.05, * * * \mathrm{p}<0.01$} \\
\end{tabular}

\section{DISCUSSION}

There is no sufficient evidence to support the first hypothesis on flextime $\left(\mathrm{H}_{1}\right)$ - flextime has a positive relationship with productivity. The Pearson correlation shows no statistical significance, yet the full regression model shows marginal significance $(\mathrm{p}<0.10)$. The study also looked into different genders and variables, the flextime variable still did not show any significance. The results are not consistent with the findings of prior studies (Baltes, et al., 1999; Holly Jr et al., 1976; Thompson \& Aspinwall, 2009; Lambert, 2006). The small sample size may attribute to the study results.

This study proves the second hypothesis on motivation $\left(\mathrm{H}_{2}\right)$ correct. The results show strong evidence that motivation makes a significant impact on productivity. The Pearson correlation model, full regression model, reduced model 1 with three variables, and the female model show statistical significance $(\mathrm{p}<0.01)$ while the male model does not. It appears female employees are more productive if motivated, compared to male employees. When motivation was compared with work life balance and job satisfaction, motivation was the biggest productivity factor.

Data supports the third hypothesis on the job satisfaction $\left(\mathrm{H}_{3}\right)$ - If an employee is satisfied more with his job, he tends to be more productive. Results show statistical significances in the four models: Pearson correlation ( $<<0.01)$, full regression model $(\mathrm{p}<0.05)$, reduced model with three factors $(\mathrm{p}<0.10)$, and male model $(\mathrm{p}<0.5)$.

Evidence shows mixed results on the fourth hypothesis on the work-life balance $\left(\mathrm{H}_{4}\right)$ - If an employee is given more work-life balance, he will be more productive. Data shows strong correlation between work-life balance and productivity $(\mathrm{p}<0.05)$ while all the four regression models report no statistical significance. This research provides weak evidence compared to the prior studies (Masuda et al., 2010); Hill et al., 2001; Rocereto et al., 2011).

The fifth hypothesis on social media $\left(\mathrm{H}_{4}\right)$ has no data support whatsoever in this study. The Pearson correlation as well as the full regression model show no statistical significance. Statistical results of this paper do not align with 
prior studies on social networking (Bennett et al., 2009; Magnier-Wantanabe et al., 2010). A small sample size may cause the outcome. There is an interesting finding from the full regression model. The social media seems negative impact on the productive.

\section{CONCLUSION}

This paper conducts an empirical study and develops multiple regression models to explain the relationship between five variables and their effects on productivity. Evidence shows that motivation, and job satisfaction affects organizational productivity. Data shows flextime and social media have no significant impacts on productivity while work-life balance is inconclusive.

Further studies on this subject can investigate the impact these variables have on organizational productivity. The validity of the research can be improved through an increase in sample size and a longer research time allowance. Future research should consider different productivity factors between small vs. large businesses and urban areas vs. rural areas. Other multivariate statistical models may also be useful to provide a diversified analysis among factors. In addition to flextime, motivation, job satisfaction, work-life balance, and social networking, workplace environment and technology directed specifically at growing efficiency can be discovered in relation to productivity. Further studies can consider variables such as employee engagement levels, benefits, leadership, and environment.

This research provides productivity literature with observed evidence of the significance of job motivators on employee productivity. Evidence suggests managers can achieve increased employee productivity by enhancing employee satisfaction and increasing motivation.

\section{REFERENCES}

Asunda, P. (2010). Productivity, social networks and net communities in the workplace. Techniques, 85(5), 38-41.

Baltes, B. B., et al. (1999). Flexible and compressed workweek schedules: A meta-analysis of their effects on workrelated criteria. Journal of Applied Psychology, 84(4), 496-513.

Barney, C. E., \& Elias, S. M. (2010). Flex-time as a moderator of the job stress-work motivation relationship. Personnel Review, 39(4), 487-502.

Bennett, J., Owers, M., Pitt, M., \& Tucker, M. (2010). Workplace impact of social networking. Property Management, 28(3), 138-148.

Boston College Center for Work \& Family (2000). Measuring the impact on workplace flexibility. Available: www.bc.edu/content/dam/files/centers/cwf/research/pdf/flexexecsumm.pdf

Christensen, K. E. \& Staines, G. L. (1990). Flextime a variable solution to work/family conflict? Journal of Family Issues, 11(4), 455-476.

Combs, J. Liu, Y, Hall, A., \& Ketchen, D. (2006). How much do high-performance work practices matter? A metaanalysis of their effects on organizational performance. Personnel Psychology, 59(1), 501-528.

Dunham, R. B., Pierce, J. L., \& Castaneda, M. B. (1987). Alternative work schedules: Two filed quasi-experiments. Personnel Psychology, 40(1), 215-242.

Shepard III, E. M., Clifton, T. J., \& Kruse, D. (1996). Flexible work hours and productivity: Some evidence from the pharmaceutical industry. Industrial Relations, 35(1), 123.

Ezra, M., \& Deckman, M. (1996). Balancing work and family responsibilities: Flextime and child care in the federal government. Public Administration Review, 56(2), 174. 
Halkos, G., \& Bousinakis, D. (2010). The effect of stress and satisfaction on productivity. International Journal of Productivity and Performance Management, 59(5), 415-431.

Hill, E. J., Alan J. Hawkins, A. J., Ferris, M. \& Weitzman, M. (2001). Finding an extra day a week: The positive influence of perceived job flexibility on work and family life balance. Family Relations, 50(1), 49-58.

Holley Jr, W. H., Armenakis, A. A., \& Field Jr, H. S. (1976). Employee reactions to a flextime program - A longitudinal study. Human Resource Management, 15(4), 21-32.

Lambert, A. D. (2006). Individual differences: Factors affecting employee utilization of flexible work arrangements. (Order No. 3233294, State University of New York at Albany). ProQuest Dissertations and Theses, 87-87.

Leader-Chivée, L., Hamilton, B. A., \& Cowan, E. (2008). Networking the way to success: Online social networks for workplace and competitive advantage. People and Strategy, 31(4), 40-46.

Lori, F. T., \& Aspinwall, K. R. (2009). The recruitment value of work/life benefits. Personnel Review, 38(2), 195210.

Lucas, J. L., \& Heady, R. B. (2002). Flextime commuters and their driver stress, feelings of time urgency, and commute satisfaction. Journal of Business and Psychology, 16(4), 565.

Magnier-Watanabe, R., Yoshida, M., \& Watanabe, T. (2010). Social network productivity in the use of SNS. Journal of Knowledge Management, 14(6), 910-927.

Meister, J. (2013). Want to be a more productive employee? Get on social networks. Forbes, Available: www.forbes.com/sites/jeannemeister/2013/04/18/want-to-be-a-more-productive-employee-get-on-socialnetworks.

Mcnall, L. A., Nicklin, J. M., \& Masuda, A. D. (2010). A meta-analytic review of the consequences associated with work-family enrichment. Journal of Business and Psychology, 25(3), 381-396.

Powell, T. (2012). Unleashing the power of social media to improve employee productivity. CPA Practice Management Forum, 8(7), 7-11.

Ralston, D. A., Anthony, W. P., \& Gustafson, D. J. (1985). Employees may love flextime, but what does it do to the organization's productivity? Journal of Applied Psychology, 70(2), 272-279.

Ralston, D. A. \& Flanagan, M. F. (1985). The effect of flextime on absenteeism and turnover for male and female employees. Journal of Vocational Behavior, 26(2), 206-217. Available: www.sciencedirect.com/science/article/pii/0001879185900193

Regus (2011). Flexible working goes global. Available: www.regus.com/images/Regus\%20Whitepaper\%20Flexible\%20Working\%20150311tcm8-39644.pdf

Rocereto, J. F., Gupta, S. F., \& Mosca, J. B. (2011). The role of flextime appeal on family and work outcomes among active and non-active flextime users: A between groups and within groups analysis. Journal of Business \& Economics Research, 9(3), 57-65.

Rodgers, C. S. (1992). The flexible workplace: What have we learned? Human Resource Management, 31(1), 183199. doi: 10.1002/hrm.3930310305

Kauffeld, S., Jonas, E., \& Frey, D. (2004). Effects of a flexible work-time design on employee- and company-related aims. European Journal of Work and Organizational Psychology, 13(1), 79-100, DOI: $10.1080 / 13594320444000001$ 


\section{Issues in Information Systems}

Volume 19, Issue 4, pp. 35-43, 2018

Sladek, C., \& Hollander, E. (2009). Where is everyone? the rise of workplace flexibility. Benefits Quarterly, 25(2), $17-22$.

Wickramasinghe, V., \& Jayabandu, S. (2007). Towards workplace flexibility: Flextime arrangements in Sri Lanka. Employee Relations, 29(6), 554-575. 